\title{
Identifikasi Pencemaran Airtanah Bebas Menggunakan Geolistrik di Lokasi Sekitar Industri Penyamakan Kulit
}

\author{
Dimas A. Wibowo ${ }^{\star}$ Puguh D. Raharjo, Eko Puswanto, Sueno Winduhutomo, Mohammad Al Afif, dan Sugeng P. \\ Saputro
}

Balai Informasi dan Konservasi Kebumian, Pusat Penelitian Geoteknologi - Lembaga Ilmu Pengetahuan Indonesia

Koresponden Email: dimasaryowibowo@rocketmail.com

Direvisi: 2020-11-11. Diterima: 2021-01-15

(C)2021 Fakultas Geografi UGM dan Ikatan Geograf Indonesia (IGI)

\begin{abstract}
Abstrak Identifikasi pencemaran airtanah pada limbah cair penyamakan kulit dapat dilakukan dengan metode geolistrik karena limbah cair industri penyamakan kulit mengandung unsur logam berat krom yang berpengaruh terhadap nilai Daya Hantar Listrik (DHL) dan nilai tahanan jenis airtanah. Penelitian ini dilakukan di sebagian Desa Sitimulyo, Piyungan, Bantul. Oleh karena itu tujuan dari penelitian ini adalah 1) memetakan pencemaran airtanah oleh limbah cair industri penyamakan kulit berdasarkan persebaran nilai DHL dan 2) mengidentifikasi pencemaran airtanah oleh limbah cair di sekitar kawasan industri penyamakan kulit berdasarkan nilai tahanan jenis. Metode penelitian ini menggunakan pengukuran tinggi muka airtanah dan DHL sebanyak 36 titik sumur, pendugaan geolistrik metode Electrical Resistivity Tomography (ERT) sebanyak 3 lintasan dengan kedalaman sebesar 11,8 m-15,9m serta uji kandungan krom pada air limbah cair dan airtanah sebanyak 10 sampel air. Uji kandungan krom pada air limbah cair dan airtanah digunakan sebagai validasi data. Hasil penelitian menunjukkan bahwa telah terjadi pencemaran airtanah bebas di sekitar kawasan industri penyamakan kulit dan disekitar saluran drainase yang tidak kedap air. Hal ini dikarenakan nilai DHL airtanah sebesar $>900 \mu \mathrm{mhos} / \mathrm{cm}$, nilai tahanan jenis airtanah $<10 \Omega$ meter, dan kandungan krom pada sampe air $>0,05 \mathrm{mg} / \mathrm{L}$. Pencemaran airtana di titik geolistrik 1 (G1) teridentifikasi pada kedalaman 5 meter dengan nilai tahanan jenis antara 3,30-9,16 $\Omega$ meter. Hal in dikonfirmasi dengan nilai DHL pada sumur terdekat G1 memiliki nilai DHL sebesar $1613 \mu \mathrm{mhos} / \mathrm{cm}$. Pada titik geolistrik 2 (G2), pencemaran airtanah teridentifikasi pada kedalaman 7 meter dengan nilai tahanan jenis 3,05-7,81 $\Omega$ meter. Nilai DHL sumur terdekat dengan titik G2 adalah sebesar $1516 \mu$ mhos/cm. Selanjutnya di titik geolistrik 3 (G3), pencemaran airtanah teridentifikasi pada kedalaman 3,73 meter dengan nilai tahanan jenis 1,33-8,61 $\Omega$ meter dengan nilai DHL sumur terdekat $1144 \mu \mathrm{mhos} / \mathrm{cm}$.
\end{abstract}

Kata kunci : pencemaran airtanah, DHL, geolistrik, tahanan jenis

Abstract Identification of groundwater contamination in leather tanning liquid waste can be carried out by using the geoelectric method because the tannery industrial liquid waste contains heavy metal elements chromium which affect the value of electrical conductivity (DHL) and the value of groundwater resistivity. This research was conducted in a part of Sitimulyo Village, Piyungan, Bantul. Therefore, the objectives of this study are 1) to map the groundwater pollution by the tannery industrial liquid waste based on the distribution of the value of DHL and 2) to identify groundwater contamination by liquid waste around the tannery industrial area based on the resistivity value. This research method uses groundwater level measurements and DHL as many as 36 well points, geoelectric estimation of the Electrical Resistivity Tomography (ERT) method for 3 passes with a depth of $11.8 \mathrm{~m}-15.9 \mathrm{~m}$ and a test of the chromium content in liquid wastewater and groundwater as much as 10 water sample. The chromium content test in wastewater and groundwater was used as data validation. The results showed that there has been contamination of unconfined groundwater around the tannery industrial area and around non-waterproof drainage channels. This is because the groundwater DHL value is $>500 \mu \mathrm{mhos} / \mathrm{cm}$, the groundwater resistivity value is $<10 \Omega$ meter, and the chromium content of the water sample is $>0.05 \mathrm{mg} / \mathrm{L}$. Water pollution at geoelectric point 1 (G1) was identified at a depth of 5 meters with a resistivity value between 3.30-9.16 $\Omega$ meter. This is confirmed by the DHL value of the nearest well G1 which has a DHL value of 1613 umhos / cm. At geoelectric point 2 (G2), groundwater contamination is identified at a depth of 7 meters with a resistivity value of 3.05-7.81 Smeter. The DHL value of the well closest to point G2 is $1516 \mu$ mhos / cm. Furthermore, at geoelectric point 3 (G3), groundwater contamination was identified at a depth of 3.73 meters with a resistivity value of 1.33-8.61 Smeter with the nearest well's DHL value of $1144 \mu \mathrm{mhos} / \mathrm{cm}$.

Keywords: Groundwater pollution, DHL, geolectrical, resistivity

\section{PENDAHULUAN}

Air adalah salah satu kebutuhan paling dasar manusia. Pertumbuhan penduduk dan kemajuan pembangunan menyebabkan kebutuhan akan air bersih menjadi meningkat. Namun, kerusakan lingkungan dan pencemaran dapat menyebabkan sumber air bersih berkurang. Sumber airtanah memiliki kerentanan terhadap pencemaran oleh aktivitas manusia seperti pertanian, urbanisasi dan industri. Pencemaran menyebabkan penurunan kualitas airtanah, oleh karena itu pencegahan adalah strategi yang paling tepat dalam melawan polusi airtanah saat ini (Kazakis \& Voudouris, 2015; Suryadi \& Notodarmojo, 2017).Pengaruh antropologis terhadap airtanaholeh penggunaan lahan, dapat memengaruhi kondisi airtanah. Bahkan, penggunaan lahan dapat mempengaruhi air untuk mengisi ulang, pasokan air dan perubahan kualitas air(Lernerdan Harris, 2009; Rahmawati \& Marfa'i, 2013).

Limbah cair yang dihasilkan industri penyamakan kulit berasal dari tahapan-tahapan yang dilakukan didalam proses penyamakan kulit menggunakan bahan kimia. Salah satu bahan kimia yang digunakan dalam industri penyamakan kulit yaitu krom. Logam krom merupakan jenis limbah 
bahan berbahaya dan beracun (B3) yang dapat mencemari air dan berbahaya bagi kesehatan. Limbah bahan berbahaya dan beracun (B3) adalah limbah yang mengandung bahan berbahaya dan atau beracun, yang karena sifat dan atau konsentrasinya, baik secara langsung maupun tidak langsung dapat merusak dan mencemari lingkungan hidup, dan atau dapat membahayakan manusia (Manik, 2003).

Industri penyamakan kulit di Daerah Istimewa Yogyakarta salah satunya terletak di Desa Sitimulyo, Kecamatan Piyungan, Kabupaten Bantul, Provinsi Daerah Istimewa Yogyakarta. Industri yang bergerak di bidang penyamakan kulit tersebut berpotensi menghasilkan limbah di dalam proses atau kegiatan industri.

Saluran pembuangan limbah cair yang dihasilkan dari kegiatan industri melewati daerah permukiman. Saluran drainase yang tidak kedap air dapat memungkinkan limbah meresap ke dalam tanah dan masuk ke sistem akuifer airtanah sehingga mencemari airtanah. Hal itu dibuktikan dengan kualitas airtanah dipermukiman sekitar saluran drainase yang agak berbau.

Perkembangan studi tentang kualitas air terutama pencemaran air sangat menarik untuk dikaji. Banyak metode yang digunakan untuk mengkaji tentang pencemaran air salah satunya dengan metode pendugaan geolistrik. Metode pendugaan geolistrik adalah metode dengan memanfaatkan sifat resistivitas listrik batuan untuk mendeteksi dan memetakan formasi bawah permukaan (Ngadimin dan Handayani, 2001). Metode ini dapat menggambarkan formasi bawah permukaan berdasarkan sifat DHL batuan dimana sifat tersebut dapat dipengaruhi oleh sifat DHL fluida yang ada di dalam pori batuan tersebut. Survei geolistrik memiliki beberapa metode dan salah satu metode survei geolistrik adalah Electrical Resistivity Tomography (ERT). ERT adalah metode yang baik digunakan untuk penelitian lingkungan dan pendeteksi pencemaran (Daily et al. 1998 ; Goes and Meekes, 2004; Hee Sang Ha et al., 2009). Hal tersebut membuktikan bahwa metode geolistrik ERT dapat digunakan untuk mengidentifikasi pencemaran yang berada di bawah permukaan tanah.

Oleh karena itu tujuan dari penelitian ini adalah 1) memetakan pencemaran airtanah oleh limbah cair industri penyamakan kulit berdasarkan persebaran nilai DHL di sekitar industri penyamakan kulit Desa Sitimulyo, Piyungan, Bantul, 2) mengidentifikasi pencemaran airtanah di sekitar kawasan industri penyamakan kulit berdasarkan nilai tahanan jenis.

\section{METODE PENELITIAN \\ Lokasi Penelitian}

Penelitian dilakukan di daerah sekitar kawasan industri penyamakan kulit di Desa Sitimulyo Kecamatan Piyungan Kabupaten Bantul. Daerah penelitian meliputi 3 dusun di Desa Sitimulyo yaitu Dusun Banyakan 1, Dusun Banyakan 2, dan Dusun Banyakan 3 (Gambar 1).

Penelitian ini menggunakan metode geolistrik sebagai alat untuk mengidentifikasi adanya pencemaran airtanah oleh limbah cair industri penyamakan kulit. Namun sebelum melakukan pengukuran geolistrik, peneliti melakukan pendugaan awal dengan melakukan pemetaan muka airtanah, aliran airtanah, dan pemetaan kandungan DHL airtanah. Penjelasan metodologi lebih jelasnya adalah sebagai berikut:

\section{Alat dan Bahan}

Alat yang diperlukan pada penelitian ini yaitu satu set seperangkat geolistrik, meteran gulung, GPS (Global Positioning System), Electrical ConductivityLF.191, dan botol sampel air. Adapun bahan yang diperlukan meliputi (1) Peta Rupa Bumi Indonesia lembar Timoho, (2) Peta Administrasi Desa Sitimulyo, (3) Peta Geologi Regional lembar Yogyakarta, dan Citra Google Earth.

Data yang diperlukan dalam penelitian ini meliputi:

A. Data geohidrologi meliputi kedalaman muka airtanah dan nilai DHL airtanah disekitar kawasan industri penyamakan kulit

B. Data karakteristik geomorfologi meliputi proses geomorfologi

C. Data geologi

\section{Metode Analisis Data Geohidrologi}

Data muka airtanah bebas diperoleh dari pengukuran kedalaman muka airtanah yang dilakukan di lapangan. Data muka airtanah bebas sebanyak 36 sumur diolah menjadi peta kontur airtanah dengan metode three point problem (Todd, 1908). Garis kontur airtanah digunakan untuk mengetahui arah aliran airtanah. Data nilai DHL ini digunakan untuk membuat peta pencemaran airtanah bebas berdasarkan persebaran nilai DHL dan menentukan titik pendugaan geolistrik.

Analisis data yang digunakan yaitu analisis deskriptif untuk menjelaskan terkait bagaimana limbah cair dapat mencemari airtanah bebas di sekitar kawasan industri dan analisis komparatif untuk menjelaskan perbandingan nilai DHL antar sampel sumur sehingga dapat diketahui sumur yang tercemar dan tidak tercemar.

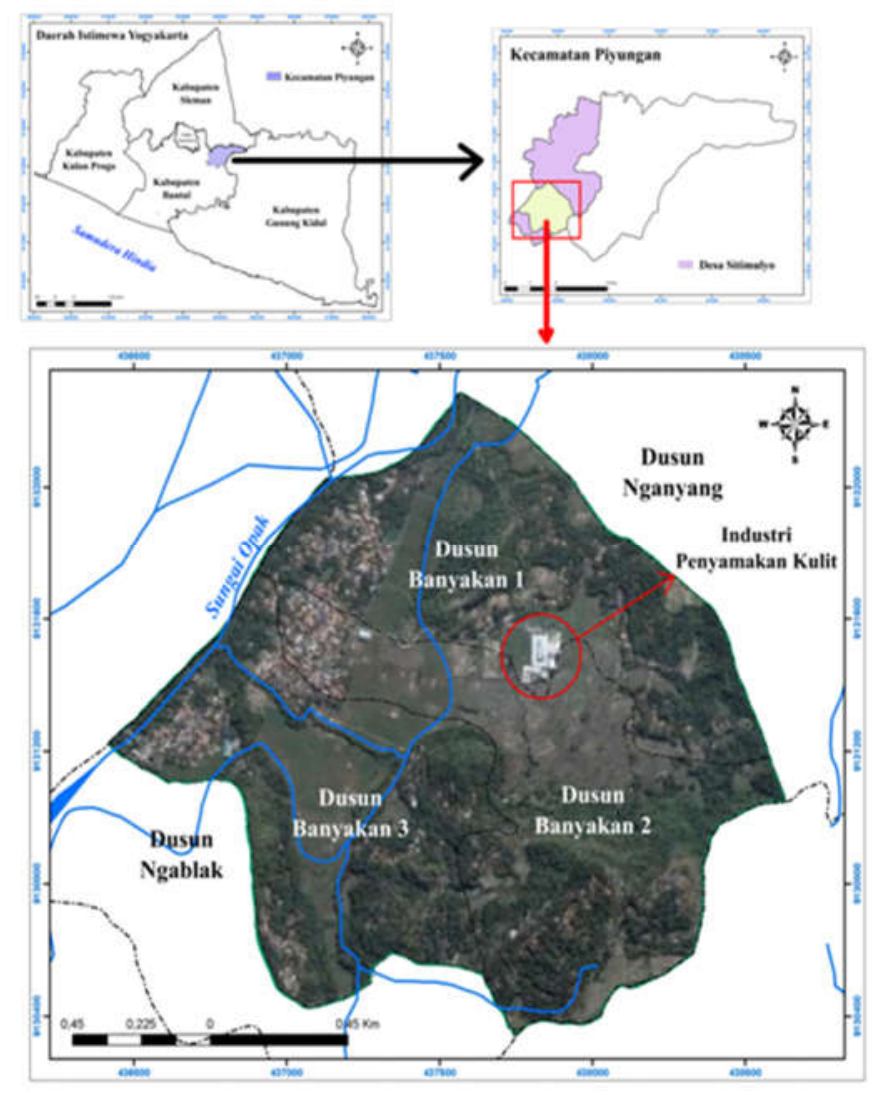

Gambar 1. Lokasi Penelitian (Modifikasi Google Earth, 2011) 
Analisis Geolistrik

Pendugaan geolistrik menggunakan metode Electrical Resistivity Tomography (ERT) konfigurasi Wenner a seperti yang ditunjukkan pada Gambar 2.

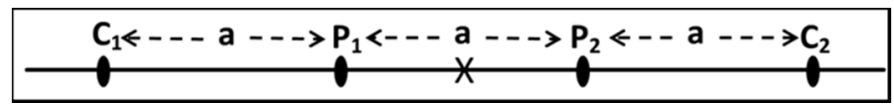

Gambar 2. Konfigurasi Wenner a (Reynolds, 1997)

Survei geolistrik ERT telah terbukti efektif dan baik dilakukan untuk mengetahui karakteristik geologi, perencanaan pembangunan, studi hidrogeologi dan terutama untuk mengidentifikasi pencemaran di bawah tanah (Chambers, et al, 2006). Konfigurasi Wenner a dipilh karena konfigurasi Wenner memiliki sensitivitas dan resolusi yang lebih baik daripada konfigurasi lainnya (Reynolds, 1997). Data tahanan jenis (resistivity) diperoleh dari pengolahan menggunakan software Res2Dinv dan X2IPI berdasarkan hasil pengukuran lapangan. Analisis pseudosection dilakukan sebagai analisis hubungan antara DHL dan resistivitas. Penentuan lokasi pengukuran geolistrik dilakukan disekitar sumur yang memiliki nilai DHL airtanah yang tinggi dengan kedalaman penetrasi lebih dari kedalaman muka airtanah. Hal ini dilakukan agar airtanah yang tercemar terdeteksi oleh geolistrik.

\section{Validasi Data}

Validasi hasil pendugaan geolistrik dilakukan dengan menggunakan uji kualitas air dengan parameter kandungan logam krom. Hal ini dilakukan karena limbah cair penyamakan kulit berpotensi mengandung logam krom. Uji kualits air dilakukan pada saluran pembuangan limbah cair dan airtanah yang diduga telah terkontaminasi limbah cair. Hasil kualitas air tersebutdibandingkan dengan baku mutu air berdasarkan baku mutu air kelas satu menurut Peraturan Gubernur Daerah Istimewa Yogyakarta no.20 Tahun 2008. Uji kualitas air tersebut untuk mengetahui kandungan logam krom dalam airtanah.

\section{HASIL DAN PEMBAHASAN \\ Geologi Regional}

Secara regional daerah penelitian terbagi menjadi 2 (dua) formasi geologi yaitu Endapan Merapi Muda (Qmi) dan Formasi Semilir (Tmse) (Gambar 2). Endapan Merapi Muda terdiri dari tuff, abu, breksi,aglomerat, dan leleran lava yang tak terpisahkan berumur Kuarter. Formasi Semilir terdiri dari perselingan antara breksi-tuff, breksi batuapung, tuff dasit, dan tuff andesit serta batulempung tuffan. Formasi Semilir berumur Oligosen akhir - Miosen awal (Rahardjo, dkk, 1995).

\section{Kondisi Geomorfologi}

Daerah penelitian memiliki tujuh bentuklahan yang terbentuk melalui berbagai proses yaitu struktural, denudasional, dan fluvial. Perbukitan asal proses struktural ini dapat dibagi lagi menjadi tiga bentuklahan yaitu bentuklahan perbukitan struktural lereng atas, perbukitan struktural lereng tengah, dan perbukitan struktural lereng bawah. Pembagian perbukitan struktural ini, berdasarkan pengelompokan kerapatan kontur pada perbukitan struktural.

Bentuklahan perbukitan struktural masuk kedalam Formasi Semilir (Tmse) yang memiliki batuan berupa perselingan antara breksi tuff, breksi batu apung, tuff dasit dan tuff andesit serta batu lempung tuffan. Kondisi tanah yang tipis di

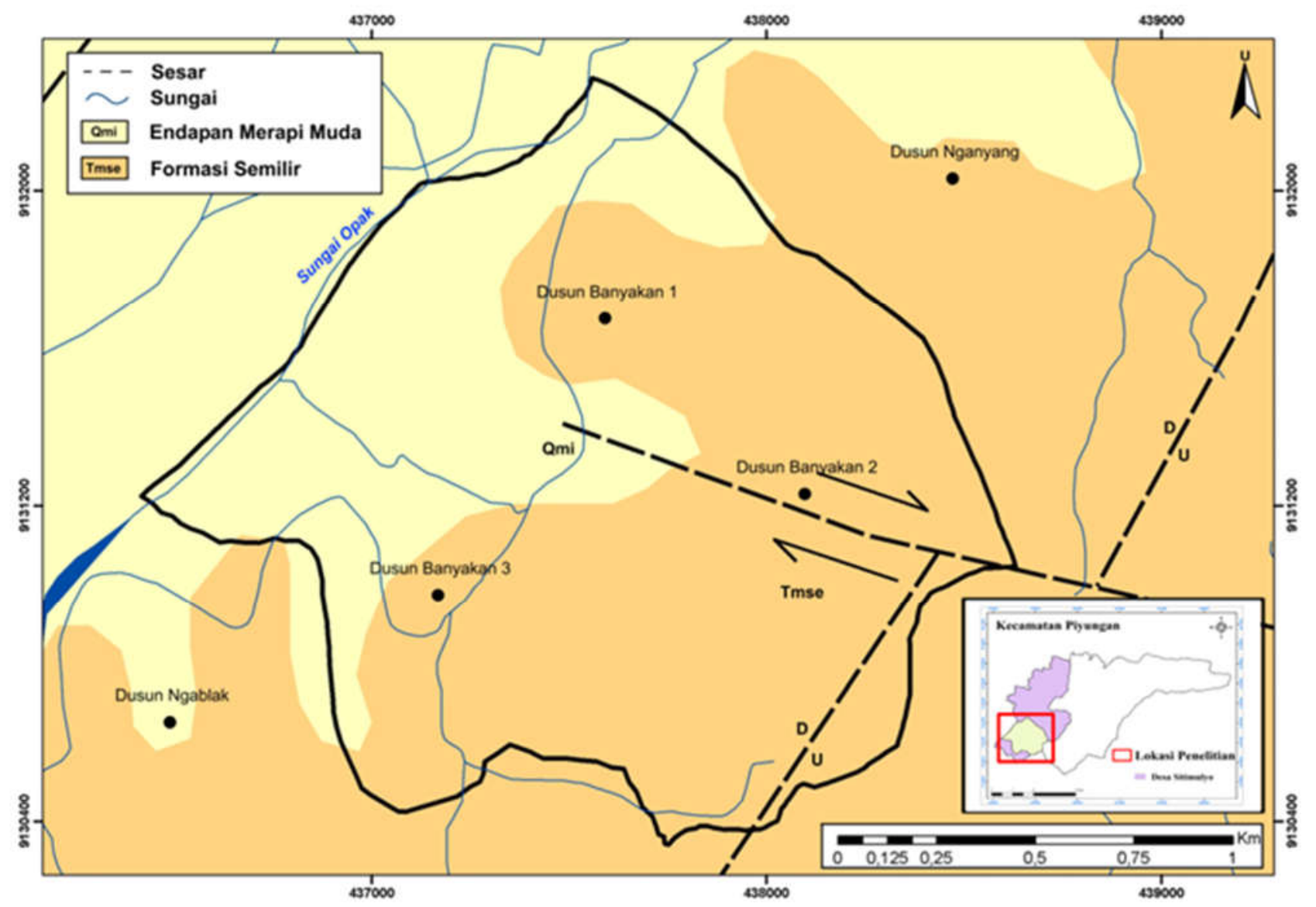

Gambar 3. Geologi Regional Daerah Penelitian (Rahardjo, dkk, 1995) 
perbukitan struktural dan adanya kontak langsung dengan batuan menyebabkan akuifer di daerah ini buruk sehingga kuantitas airtanah sangat sedikit atau tidak ada. Oleh karena itu penggunaan lahan permukiman sangat sedikit dan lebih didominasi oleh penggunaan lahan semak belukar dan tegalan serta sawah tadah hujan.

Bentuklahan yang terbentuk oleh proses denudasional di daerah penelitian adalah bentuklahan perbukitan denudasional terisolasi dan dataran kolluvial. Perbukitan denudasional terisolasi menandakan bahwa perbukitan ini memiliki batuan yang kompak dan erosi tidak dapat mengikis secara cepat sehingga tertinggal dan membentuk perbukitan yang menyendiri. Bentuklahan asal proses denudasional yang lainnya adalah dataran kolluvial. Dataran kolluvial merupakan dataran yang datar dengan material kolluvium. Material kolluvium adalah material hasil rombakan dari lereng atas yang runtuh akibat adanya erosi dan gerak massa

Bentuklahan yang terbentuk oleh proses fluvial dapat dikelompokkan menjadi dua yaitu tanggul alam dan dataran alluvial. Bentuklahan asal proses fluvial ini terbentuk oleh proses sedimentasi. Bentuklahan tanggul alam berada disekitar kanan dan kiri tepi sungai. Tanggul alam terbentuk karena adanya proses pengendapan material yang dibawa pada saat sungai banjir dan terendapkan di sekitar tepi sungai. Bentuklahan dataran alluvial mendominasi di daerah dataran pada daerah penelitian. Dataran alluvial terbentuk karena adanya proses sedimentasi oleh air menuju ketempat yang lebih rendah. Distribusi bentuklahan di daerah penelitian pada Gambar 4.
Kondisi Geohidrologi

Arah aliran airtanah digunakan untuk mengidentifikasi sumur-sumur yang airtanahnya telah tercemar dan sumber pencemarannya(Gambar 6.). Kontur airtanah pada daerah penelitian dibagi menjadi tiga bagian berdasarkan kondisi topografi lereng daerah penelitian. Hal ini dikarenakan perbedaan topografi lereng dan sistem akuifer. Selain itu tidak terdapat sumur gali disekitar penggunaan lahan sawah irigasi atau pada sebagian bentuklahan dataran kolluvial dan dataran alluvial di sekitar industri penyamakan kulit sehingga kondisi airtanah pada penggunaan lahan tersebut tidak dapat diukur.

Berdasarkan Gambar 5. dapat diketahui bahwa terdapat cekungan airtanah atau cone of depression. Cekungan airtanah tersebut terjadi karena kondisi alamiah sehingga menyebabkan limbah cair industri penyamakan kulit terakumulasi dan mencemari airtanah. Cekungan airtanah ini membuktikan bahwa pencemaran airtanah tertinggi terjadi pada daerah yang memiliki tinggi muka airtanah paling rendah.

Nilai DHL airtanah daerah penelitian dipengaruhi oleh arah aliran airtanah. Aliran airtanah yang terpusat maka nilai DHL airtanah akan tinggi. Semakin tercemar airtanah oleh limbah cair industri penyamakan kulit yang mengandung logam krom maka nilai DHL-nya juga semakin meningkat. Persebaran nilai konduktivitas di daerah penelitian berkisar 139-1613 $\mu \mathrm{mhos} / \mathrm{cm}$ berdasarkan pengukuran langsung di lapangan. Hal ini mengindikasikan bahwa air sumur tersebut telah tercemar atau $>900 \mu \mathrm{mhos} / \mathrm{cm}$ sedangkan nilai DHL airtanah belum tercemar $<900 \mu \mathrm{mhos} / \mathrm{cm}$ (Davis, 1996 ;

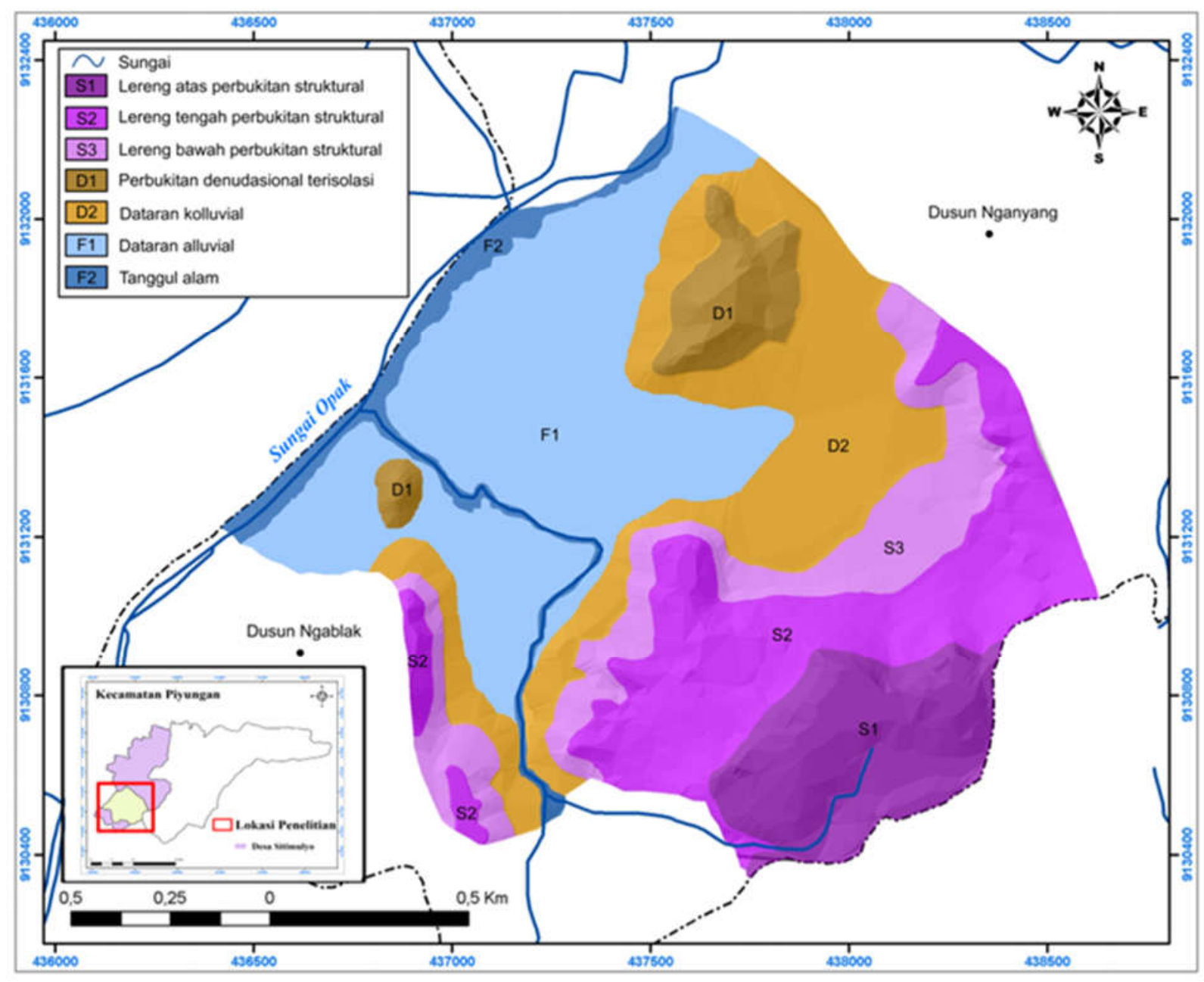

Gambar 4. Bentuklahan di sebagian Desa Sitimulyo (Pengolahan data, 2011) 
Pryambodo, dkk, 2017).

Nilai DHL airtanah tertinggi terletak pada bentuklahan dataran alluvial (Gambar 8.). Pada bentuklahan alluvial, nilai DHL airtanah berkisar 326-1613 $\mu \mathrm{mhos} / \mathrm{cm}$ (Tabel 1). Sumur yang airtanahnya memiliki nilai DHL tertinggi terletak dekat dengan saluran drainase tidak kedap air yang membawa limbah cair hasil pembuangan dari industri penyamakan kulit. Hal tersebut dapat dari anomali nilai DHL yang tinggi disekitar saluran drainase tidak kedap air dibandingkan dengan daerah sekitarnya.

Tingkat pencemaran airtanah yang tinggi terdapat di bentuklahan dataran alluvial yang sebagian besar penggunaan lahannya berupa pemukiman yang dekat dengan industri penyamakan kulit dan di sekitar saluran alami pembuangan limbah cair atau saluran drainase yang tidak kedap air. Dataran alluvial mempunyai elevasi yang rendah dari pada daerah sekitarnya dan memiliki akuifer yang baik sehingga mudah untuk menyalurkan dan menyimpan airtanah yang tercemar. Bentuklahan dataran kolluvial pun memiliki pencemaran airtanah yang tinggi karena daerah tersebut dekat dengan industri penyamakan kulit. Arah aliran airtanah di sekitar sumber pencemar menuju ke utara mengakibatkan nilai DHL di utara industri penyamakan kulit juga tinggi meskipun secara elevasi permukaan tanah, elevasi diutara industri lebih tinggi namun tinggi muka airtanah di utara industri penyamakan kulit lebih rendah (aliran airtanah terpusat) (Gambar 5.). Daerah yang memiliki pencemaran airtanah tinggi digunakan sebagai titik pengukuran pendugaan geolistrik untuk memastikan pencemaran airtanah yang terjadi dibawah permukaan tanah di bentuklahan tersebut.

\section{Distribusi Pencemaran Airtanah dari Interpretasi ERT}

Pengukuran geolistrik dilakukan sebanyak tiga rentangan di tiga lokasi yang berbeda (Gambar 8.). Lokasi pengukuran geolistrik pertama (G1) terletak di Dusun Banyakan 3 di permukiman padat sekitar saluran drainase yang tidak kedap air. Nilai DHL di sekitar pengukuran geolistrik sebesar 1613 $\mu \mathrm{mhos} / \mathrm{cm}$. Pengukuran geolistrik titik pertama (G1) berjarak rentangan 75 meter dengan spasi antar elektroda 1,5 meter dan arah rentangan utara ke selatan.

Berdasarkan pseudosection secara vertikal (Gambar 6.) kedalaman G1 yang diperoleh sekitar 11,8 meter dan secara horizontal sepanjang 4-72 meter. Kedalaman airtanah atau akuifer di sekitar G1 adalah 4 meter. Pada kedalaman 2,81 meter di bawah permukaan tanah terlihat material lempung. Pada titik G1 terlihat adanya pencemaran airtanah di kedalaman sekitar 5 meter dengan nilai resistivitas 3,30-9,16 Smeter. Berdasarkan penelitian Srinivasamoorthy, et.al (2009) di Tamilnadu State, India Selatan menunjukkan bahwa airtanah yang tercemar memiliki nilai resistivitas $<10$ Smeter. Pada titik G1 pada bentuklahan dataran alluvial sehingga terlihat material berupa alluvium dan terdapat selingan batuan breksi pada kedalaman 0,281-4 meter dengan resistivitas 10-36,7 $\Omega$ meter.

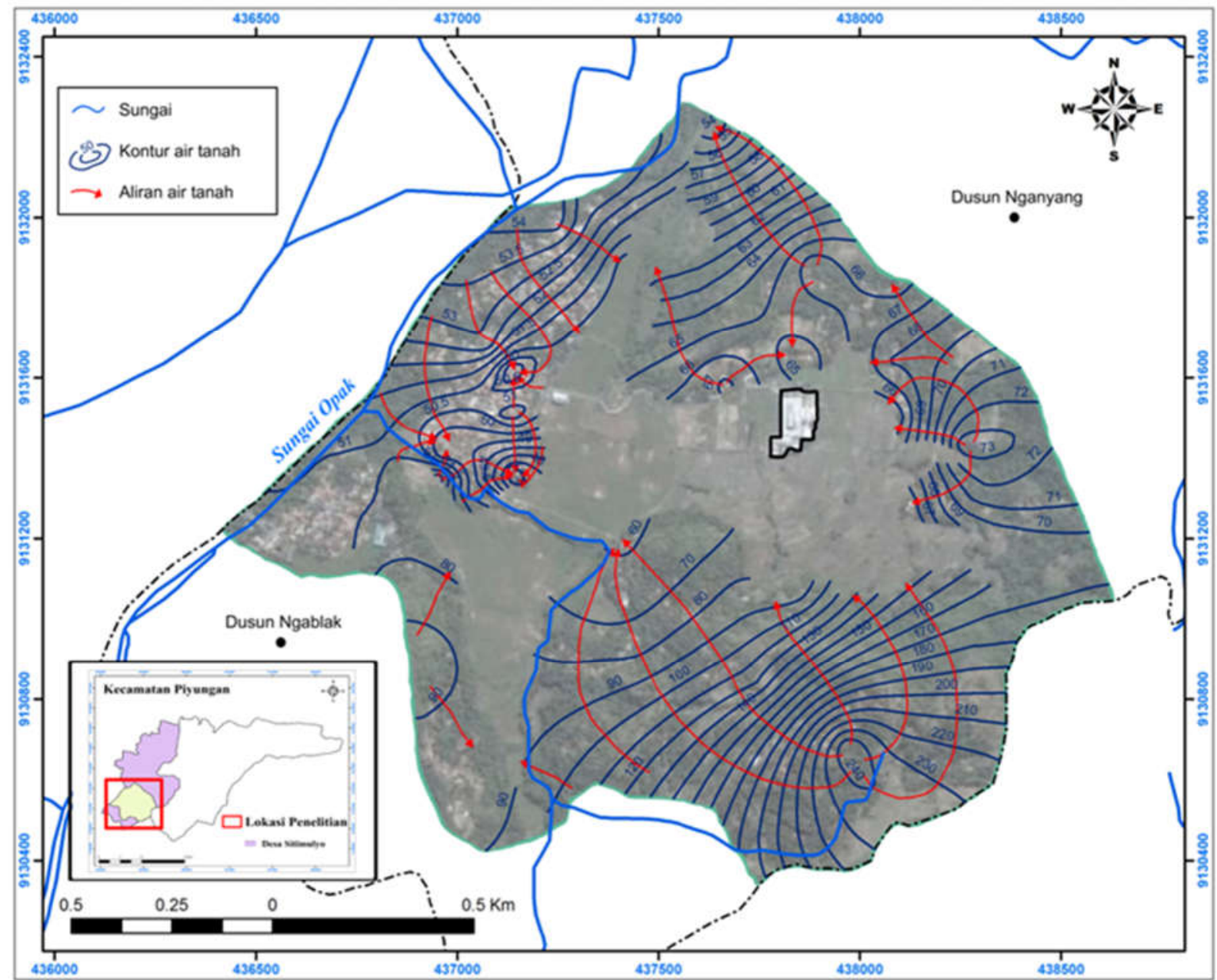

Gambar 5. Kontur dan arah aliran airtanah daerah penelitian (Pengolahan data, 2011) 

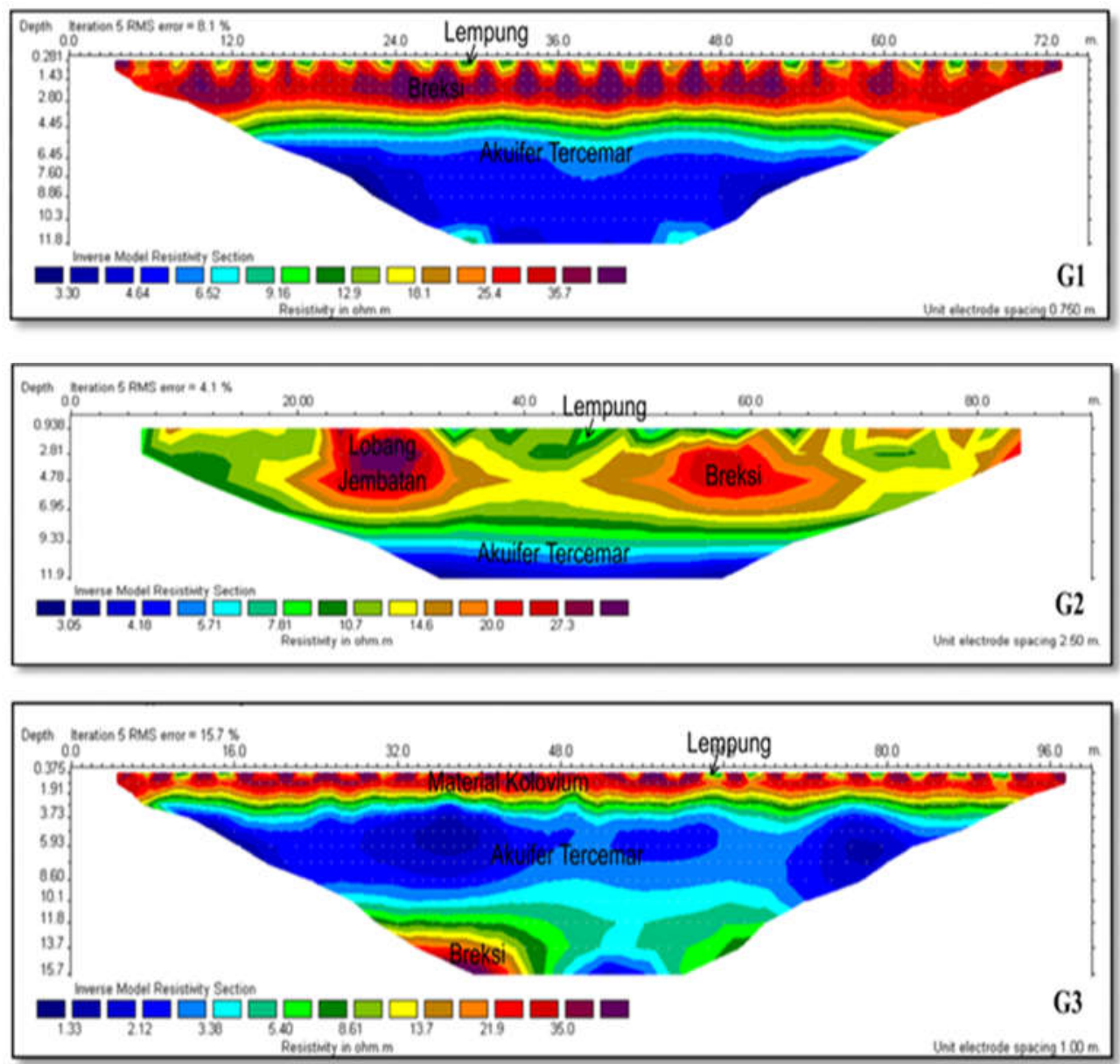

Gambar 6. Intepretasi Geolistrik (Analisis data, 2011)

Tabel 1. Nilai DHL pada satuan bentuklahan

\begin{tabular}{ll}
\hline $\begin{array}{l}\text { Nilai DHL }(\mu \mathrm{mhos} / \\
\mathrm{cm})\end{array}$ & Satuan Bentuklahan \\
\hline $139-183$ & $\begin{array}{l}\text { Lereng atas perbukitan struktural } \\
\text { Lereng tengah perbukitan } \\
\text { struktural }\end{array}$ \\
& $\begin{array}{l}\text { Lereng bawah perbukitan } \\
\text { struktural }\end{array}$ \\
$215-587$ & Dataran kolluvial \\
$289-1144$ & Dataran alluvial \\
\hline
\end{tabular}

(Sumber : Pengolahan data primer, 2011)

Pengukuran geolistrik yang kedua (G2) dilakukan di sekitar pemukiman padat penduduk di Dusun Banyakan 3. Panjang rentangan pada pengukuran G2 berjarak 90 meter dengan spasi antar elektroda sebesar 5 meter. Jarak spasi elektroda yang relatif jauh dikarenakan pertimbangan arah rentangan yang memotong jalan aspal. Pada gambar tersebut pseudosection G2 kedalaman yang diperoleh adalah 11,9 meter dengan horizontal sekitar 7-83 meter. Akuifer tercemar teridentifikasi pada kedalaman 7 meter dengan nilai resistivitas 3,05-7,81 $\Omega$ meter. Perlapisan material pada G2 terdiri dari alluvium, akuifer dan terdapat bongkah batuan breksi. Pada gambar tersebut juga terlihat lingkaran yang nilai resistivitasnya tidak teridentifikasi karena lingkaran tersebut merupakan lubang jembatan yang dilewati pengukuran G2 (Gambar 7.).

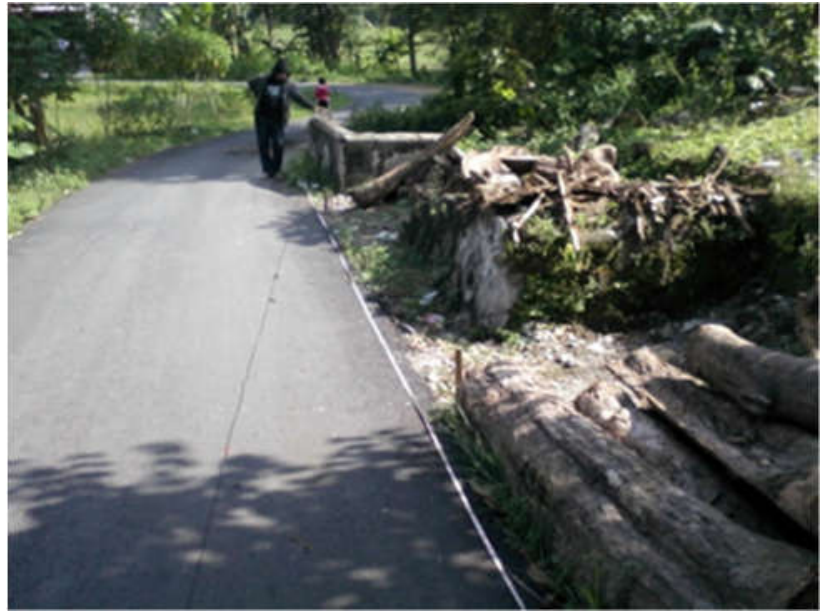

Gambar 7. Lintasan G2 (Wibowo, 10 Maret 2011) (Koordinat : 49 M 437028, 9131395)

Lokasi pengukuran geolistrik ketiga (G3) dilakukan di permukiman sekitar industri penyamakan kulit. Panjang rentangan berjarak 100 meter dengan spasi antar elektroda 2 meter dan arah rentangan dari timur ke barat. Berdasarkan interpretasi hasil pseudosection G3 diketahui bahwa perlapisan material kolluvium memiliki kedalaman sampai 2 meter dengan nilai resistivitas $>21,9 \Omega$ meter. Material kolluvium berasal dari proses sedimentasi sehingga mudah menyerap dan meloloskan air. Oleh karena itu material kolluvium rentan terhadap pencemaran airtanah apabila air permukaan pada daerah tersebut telah tercemar. Akuifer yang 
telah tercemar mempunyai nilai resistivitas sebesar 1,33-8,61 Smeter pada kedalaman 3,73 meter di bawah permukaan tanah.Hal tersebut divalidasi dengan hasil uji krom airtanah disekitarnya. Material breksi terlihat pada kedalaman 13,7 meter di bawah permukaan tanah dengan resistivitas $>35$ Smeter. Total kedalaman pada pengukuran G3 adalah 15,7 meter di bawah permukaan tanah dan secara horisontal jarak yang diperoleh sekitar 5-98 meter.

\section{Validasi Sampel Air}

Pengambilan sampel air dilakukan pada saluran drainase dan air sumur yang terindikasi tercemar. Pengambilan sampel air pada saluran drainase untuk membuktikan bahwa limbah yang mencemari airtanah berasal dari industri penyamakan kulit karena limbah penyamakan kulit mengandung krom yang tinggi. Sampel air no. 1 - 4 merupakan sampel air ang diambil pada saluran drainase sedangkan sampel air no. 5-10 merupakan sampel airtanah. Sampel no. 1 yang merupakan limbah cair keluar langsung dari industri penyamakan kulit mengandung unsur logam krom yang sangat tinggi $(54,6091 \mathrm{mg} / \mathrm{l})$. Nilai DHL limbah cair pada sampel no. 1 ini juga sangat tinggi yaitu sebesar $3070 \mu$ mhos/ $\mathrm{cm}$. Hal ini membuktikan bahwa limbah cair buangan langsung industri penyamakan kulit berbahaya apabila mencemari airtanah dan terkonsumsi oleh manusia. Pada Gambar 8. terlihat bahwa semakin jauh jarak sampel air dari sumber pencemar yakni limbah cair industri penyamakan kulit dan saluran drainase tidak kedap air maka semakin rendah kandungan krom dan nilai DHLnya. Namun besar kecilnya kandungan krom masih dapat dipengaruhi oleh arah aliran airtanah dan jenis material batuan penyusunnya. Hal ini terlihat seperti pada sampel no. 8 yang dijadikan titik kontrol walaupun berada di sekitar industri penyamakan kulit. Kondisi muka airtanah pada titik sampel no. 8 relatif lebih tinggi dibanding sekitarnya sehingga tidak terjadi pencemaran airtanah. Hal ini membuktikan bahwa meskipun lokasi titik sampel no. 8 dekat dengan sumber pencemaran, namun tinggi muka airtanah yang tinggi dan arah aliran airtanah yang tidak mengarah ke titik sampel 8 mengakibatkan airtanah di titik tersebut tidak tercemar. Kandungan krom sampel no. 8 masih di bawah batas maksimum baku mutu air kelas satu sebesar $<0.05 \mathrm{mg} / \mathrm{L}$ berdasarkan baku mutu air kelas satu menurut Peraturan Gubernur Daerah Istimewa Yogyakarta no.20 Tahun 2008 sedangkan untuk nilai DHl tidak disebutkan pada peraturan tersebut. Perbandingan nilai tahanan jenis, DHL, dan nilai krom airtanah tercemar dilihat pada Tabel 2.

Berdasarkan Tabel 2. dapat diketahui bahwa airtanah tercemar memiliki nilai tahanan jenis yang rendah dan nilai DHL yang tinggi. Oleh karena itu hubungan nilai DHLdan nilai resistivitas berbanding terbalik. Hasil survei tahanan jenis airtanah akan lebih baik dihubungkan dengan sampel kualitas airtanah yang tercemar dimana pencemar memiliki

Tabel 2. Perbandingan nilai tahanan jenis, nilai DHL, dan nilai kandungan krom pada airtanah tercemar di titik pendugaan geolistrik

\begin{tabular}{lrrr}
\hline $\begin{array}{l}\text { Titik } \\
\text { Geolistrik }\end{array}$ & $\begin{array}{l}\text { Nilai Tahan- } \\
\text { an Jenis } \\
(\Omega \text { meter })\end{array}$ & $\begin{array}{l}\text { Nilai DHL } \\
(\mu \mathrm{mhos} / \mathrm{cm})\end{array}$ & $\begin{array}{l}\text { Nilai Kan- } \\
\text { dungan Krom } \\
(\mathrm{mg} / \mathrm{L})\end{array}$ \\
\hline G1 & $3,30-9,16$ & 1613 & 0,1407 \\
G2 & $3,05-7,81$ & 1516 & 0,0493 \\
G3 & $1,33-8,61$ & 1144 & 0,0557 \\
\hline
\end{tabular}

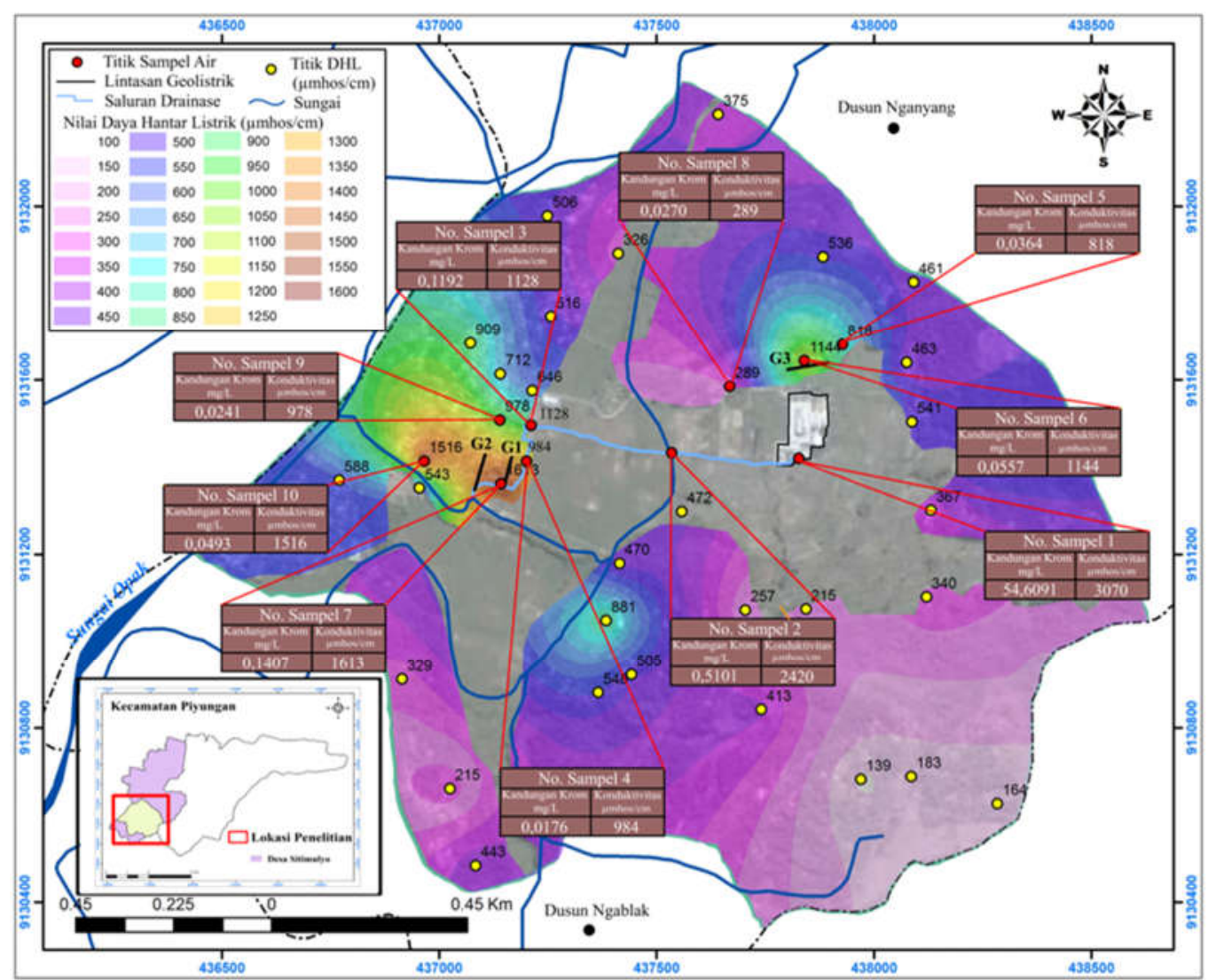

Gambar 8. Lokasi Sampel Air dan Kandungan Krom (Pengolahan data, 2011) 
nilai DHL sangat tinggi (Todd,1980). Hasil uji krom pada kualitas airtanah di titik lokasi pendugaan geolistrik ini digunakan sebagai validasi nilai resistivitas atau tahanan jenis dan DHL. Hasil uji krom tersebut juga membuktikan bahwa sebagian airtanah di sekitar industri penyamakan kulit telah tercemar limbah cair industri penyamakan kulit.

\section{KESIMPULAN}

Persebaran nilai DHL di daerah penelitian berkisar 139$1613 \mu \mathrm{mhos} / \mathrm{cm}$. Nilai DHL airtanah tertinggi terletak pada bentuklahan dataran alluvial berkisar 326-1613 $\mu \mathrm{mhos} / \mathrm{cm}$. Persebaran pencemaran airtanah yang tinggi terdapat di daerah permukiman dengan nilai konduktivitas $1613 \mu \mathrm{mhos} / \mathrm{cm}$ dan kandungan krom sebesar 0,0493 mg/l.

Airtanah yang tercemar memiliki nilai DHL dan kandungan krom yang tinggi dengan nilai tahanan jenis atau resistivitas rendah. Identifikasi pencemaran airtanah berdasarkan nilai tahanan jenis diukur menggunakan metode geolistrik Electrical Resistivity Tomography (ERT) pada tiga titik. Pada titik geolistrik pertama (G1) pencemaran airtanah terjadi pada kedalaman 5 meter dengan tahanan jenis 3,309,16 $\Omega$ meter. Di titik geolistrik kedua (G2) akuifer tercemar di kedalaman 7 meter di bawah permukaan tanah dengan nilai tahanan jenis 3,05-7,81 $\Omega$ meter. Sementara itu di titik geolistrik ketiga (G3) pencemaran airtanah teridentifikasi pada kedalaman 3,73 meter dengan nilai tahanan jenis 1,33$8,61 \Omega$ meter. Hasil uji krom tersebut juga membuktikan bahwa sebagian airtanah di sekitar industri penyamakan kulit telah tercemar limbah cair industri penyamakan kulit.

\section{UCAPAN TERIMA KASIH}

Penulis mengucapkan terima kasih kepada Dr. Tjahyo Nugroho Adji, M.Sc Tech. dari Fakultas Geografi Universitas Gadjah Mada atas dukungannya sehingga penelitian ini dapat terselesaikan penelitian dengan baik.

\section{KONTRIBUSI PENULIS}

Penulis Pertama mendesain metode penelitian, analisis data geohidrologi, dan membuat naskah publikasi; Penulis kedua analisis data dan pengolahan GIS; Penulis ketiga analisis data geologi dan interpretasi hasil; Penulis keempat analisis data geologi dan interpretasi hasil; Penulis kelima analisis data geomorfologi dan review naskah publikasi; dan Penulis keenam analisis data geomorfologi dan review naskah publikasi.

\section{DAFTAR PUSTAKA}

Davis, S.N. and Wiest, R.J.M. (1996). Hydrogeology. New York. Jhon Willey \& Sons. Inc.

Gubernur DIY. (2008). Peraturan Gubernur Daerah Istimewa Yogyakarta No.20 Tahun 2008 Tentang Baku Mutu Kelas Air. Yogyakarta.

Hee Sung Ha, Due Sang Kim, and Inn Joon Park. (2009). Application of Electrical Resistivity Techniques to Detect Week an Fracture Zones Cluving Underground Construction. Environ Earth Sci(2010) $60: 723-731$.

Kazakis, N., \&Voudouris, K.S. (2015). Groundwater vulnerability and pollution risk assessment of porous aquifers to nitrate: Modifying the DRASTIC method using quantitative parameters. Journal of Hydrology, 525,13-25.

Lerner, D.N. \& Harris, B., (2009).The relationship be- tween land use and groundwater resources and quality. Land Use Policy, 26(1), p.S265-S273.

Manik, K.E.S.(2003). Pengelolaan Lingkungan Hidup. Djambatan.
Jakarta.

Ngadimin dan Handayani, G. 2001. Aplikasi Metode Geolistrik Untuk Alat Monitoring Rembesan Limbah (Penelitian Model Fisik di Laboratorium). JMS Vol. 6 No. 1, hal. 43 - 53 April 2001.

Pryambodo, D. G., Prihantono J., dan Supriyadi. (2016). Zonasi Intrusi Air Ain Dengan Kualitas Fisik Airtanah di Kota Semarang. Jurnal Kelautan Nasional, Vol. 11, No. 2, Agustus 2016, Hal 89-95.

Rahardjo, W., Sukandarrumidi, dan Rosidi H. M. D. (1995). Peta Geologi Lembar Yogyakarta, Skala 1:100.000. Pusat Penelitian dan Pengembangan Geologi. Bandung

Rahmawati, N., \&Marfai, M.A. (2013). Salinity Pattern in Semarang Coastal City: An Overview. Indonesian Journal of Geology, Vol. 8 No. 2 June 2013: 107-118.

Reynolds, J.M. (1997). An Introduction to Applied and Enviromental Geophysics. John Wiley \& Sons Inc. New York. USA.

Srinivasamoorthy, K., Sarma, V.S., Vasantavigar, M.P., Vijayaraghavan, K., Chidambaram, S., and Rajivganthi, R., (2009). Electrical Imaging Techniques for Groundwater Pollution Studies : a Case Study From Tamilnadu State, South India. Earth Sci Res. J. Vol. 13 No. 1Bogota Jan/June 2009.

Suryadi, G.G., dan Notodarmojo, S. (2017). Optimasi Strategi Pengendalian Kerentanan Airtanah Dengan Metode Analitycal Heirarcy Prosess (StudiKasus: Kota Cimahi). Jurnal Teknik Lingkungan Volume 23 Nomor 1, Hal 61-68 April 2017.

Todd, D, K. (1980). Groundwater Hydrology. John Willey and Sons. New York. 